\title{
Ginger rhizomes (Zingiber officinale) functionality in food and health perspective: a review
}

\author{
*Indiarto, R., Subroto, E., Angeline and Selly \\ Department of Food Industrial Technology, Faculty of Agro-Industrial Technology, Universitas \\ Padjadjaran, Jl. Raya Bandung-Sumedang Km. 21, Jatinangor, Sumedang 45363, Indonesia
}

\begin{abstract}
Article history:
Received: 16 July 2020

Received in revised form: 15

August 2020

Accepted: 21 September 2020

Available Online: 12

December 2020
\end{abstract}

\section{Keywords:}

Bioactive compounds,

Food,

Ginger,

Immunity,

Toxicity,

Virus

DOI:

https://doi.org/10.26656/fr.2017.5(1).361

\begin{abstract}
Ginger is a spice type used by rhizome. Ginger has long been used to heal various diseases, including inflammation and digestive disorders. As the development of science, the food and health sector, mostly use ginger as functional food and medicine because of its usefulness. Ginger's role as food and medicine has been recognized as safe, classified in Generally Recognized as Safe (GRAS) by the Food Drug and Administration (FDA). The content of bioactive compounds in ginger classified as volatile and non-volatile compounds contributes positively to food and health. Ginger can be used as fresh, dried, essential oils, oleoresin, extracts, or powders. Oleoresin and essential ginger oil are extracts used extensively in food and health fields. To obtain the extract, an extraction that multiplies thermal and non-thermal processes can be performed. Many use gingers as a condiment for food. Ginger gives a spicy taste that's typical of food and drink. It also contributes to a natural antioxidant, extends food products' shelf-life, and improves the organoleptic quality of food products. Whereas ginger consumption can help decrease blood glucose in type 2 diabetes mellitus, analgesics, reduce uric acid, lessen muscle pain, and increase the body's immune system. In this study, we have reviewed ginger, the red ginger extraction process, and functional compounds, food, and health benefits.
\end{abstract}

\section{Introduction}

Ginger (Zingiber officinale Rosc.) is indeed a plant type from the Zingiberaceae family. Its name "Zingiber" comes from the Greek "Zingiberi" and Sanskrit "Singabera" meaning horn because the ginger rhizome has a shape nearly the same as a deer antler and the name "Officinale" comes from the Latin "Officina" meaning it is used in medicine or pharmacy (Vasala, 2012). Ginger rhizomes can be widely used in food and drinks. It's due to ginger's nature as a spicy spice and gives a savory sensation. Ginger is also used in a variety of food and beverage applications, providing specific functional properties due to their bioactive compounds (Srinivasan, 2017). You can also use ginger rhizome products in the form of fresh ginger, durable ginger, dried ginger, ginger powder, ginger essential oil, ginger oleoresin, and ginger paste (Vasala, 2012).

In traditional medicine, the ginger rhizome has long been used to treat a variety of foods to help digestion and to treat colic, diarrhea, and nausea (Sharifi-Rad et al., 2017). At present, ginger extracts of water-ethanol produce oleoresin and essential oils which contain many phenolic compounds. The compounds extracted have functional and pharmacological properties such as antioxidants, antihyperglycemic, antimicrobial, anticarcinogenic, anti-inflammatory, immunomodulatory, antilipidemic antitumor, and antimutagenic (Ali et al., 2008; Arablou and Aryaeian, 2018; Mahboubi, 2019). Phenolic compounds also have spicy properties, including volatile compounds like gingerol, shogaol, paradol, and zingerones (Ali et al., 2008; Arablou and Aryaeian, 2018; Srinivasan, 2017). It is also believed that ginger can fight the common influenza virus and influenza-like symptoms (Sahoo et al., 2016). Fresh ginger proved effective against plaque formation induced in the airway epithelium by a human respiratory syncytial virus (HRSV). Fresh ginger's role hinders virus sticking and internalizing (Chang et al., 2013). Because of these properties, ginger has also been developed to improve its functionality in the form of nanoparticles as a drug delivery with various advantages that it needs to increase the prevention and treatment of inflammatory bowel disease (Zhang et al., 2018). This review provide critical insights on ginger, its constituent bioactive compounds, bioactive compound extraction, 
food and health perspectives and potential directives for future research.

\section{Extraction and chemical composition of ginger bioactive compounds}

As just a natural remedy, ginger is a diverse herb comprising $60-70 \%$ carbohydrates, $9 \%$ protein, $8 \%$ ash, $3-6 \%$ lipids, $3-8 \%$ crude fiber, $9-12 \%$ water, and $1-3 \%$ essential oils (Kim and Kim, 2010; Mahboubi, 2019). Ginger oil's chemical composition is influenced by rhizome source, freshness, or dryness and extraction method (Mahboubi, 2019). While oleoresin, consisting of gingerol, zingiberene, shogaol, is classified as a nonvolatile component contributing to bitter and spicy taste. Zingerone is a stinging tastemaker from the ginger rhizome. It also works against Escherichia coli bacteria causing diarrhea and Bacillus subtilis as it has high zingerones and gingerol compounds (Ravindran and Babu, 2016). Gingerol provides a strong spicy taste (Baliga et al., 2013). The main compound responsible for spicy rhizomes is 6-gingerol, while some other gingerols (4-, 8-, 10- and 12-gingerol) were also available in limited amounts (Mahomoodally et al., 2019). However, because it is thermally labile, this compound is converted to shogaol at high temperatures, e.g. when cooking, giving the ginger a spicy-sweet aroma. Gingerol and shogaol biological properties have antimicrobial, anticancer, antioxidant, anti-inflammatory, and anti-allergic properties (Srinivasan, 2017; Vasala, 2012). Shogaol has an anti-coughing effect, while gingerol contributes to ginger's analgesic properties (Mao et al., 2019). Besides phenolics, diarylheptanoid and zingerone were also detected in ginger. Bioactive compounds are believed to be due to health benefits (Shukla and Singh, 2007; Febriani et al., 2018). Thereby, the nutritional supplement content of ginger is associated with the specificity of active substances, especially the main phenolic groups like gingerol, shogaol, zingiberene, paradol, and zingerone (Mao et al., 2019).

Different techniques were used to extract essential ginger oils. The most common method is the hydrodistillation (dos Santos Reis et al., 2020). Hydrodistillation, plant material undergoes a drying process aimed at inhibiting the activity of microbes and reducing the water content to ensure optimum extraction of essential ginger oil (Rahimmalek and Goli, 2013; An et al., 2016). The suggested drying time may vary from 3 to 7 days, guess it depends on the dried herb's temperature and humidity (I Rahimmalek and Goli, 2013; Indiarto and Rezaharsamto, 2020a). The drying stage can lower the volatile oil content because chemical elements are volatilized or degraded when they are excessive temperature and too long (Rahimmalek and Goli, 2013; Indiarto et al., 2019; Subroto et al., 2019). Enzymatic pretreatment is used to remove drying and improve extraction efficiency (Reis et al., 2020). It can increase the efficiency of ginger essential oil hydrodistillation by $47.95 \%$ at $40^{\circ} \mathrm{C}$ for 130 mins (dos Santos Reis et al., 2020). Various ginger extraction methods provide specific functional properties, as shown in Table 1.

\section{Ginger functionality for food}

Ginger is widely used in food processing, such as pickled ginger, biscuits, candy, gingerbread, beer (ginger ale), powder, and syrup (Vasala, 2012). Processed ginger in form ginger candy was able to reduce the rate of vomiting in pregnant women in the first trimester (Anita et al., 2020). Adding ginger extract to turmeric white drinks increases antioxidant activity. It is due to phenolic compounds in ginger, which play a role in eliminating free radicals and radicals (Lobo et al., 2010; Indiarto et al., 2019). Oleoresin in ginger contains 6-gingerol, shogaol, and zingerone, exceeding vitamin E (Sueishi et al., 2019). Gingerol and shogaol compounds in ginger that function as a spicy flavor and zingiberene that gives a warm feel (Panjaitan et al., 2012; Semwal et al., 2015). Using ginger powder in processed meatballs affects the flavor and taste of zingiberol and zingiberene compounds that contribute to the fragrant odor (Tritanti and Pranita, 2019). Using ginger powder, however,

Table 1. Ginger extraction methods and resulting functional properties

\begin{tabular}{|c|c|c|c|}
\hline Material Process & Extraction method & Functional properties & References \\
\hline $\begin{array}{l}\text { Ginger polysaccharide } \\
\text { extraction }\end{array}$ & $\begin{array}{l}\text { Hot water extraction; ultrasonic cell } \\
\text { grinder extraction; enzyme assisted } \\
\text { extraction }\end{array}$ & Antit & Liao et al. (2020) \\
\hline Ginger essential oil extraction & Crude multi-enzymatic extracts & $\begin{array}{l}\text { Phytochemical, natural additive, } \\
\text { flavoring agent }\end{array}$ & $\begin{array}{l}\text { dos Santos Reis et al. } \\
(2020)\end{array}$ \\
\hline $\begin{array}{l}\text { Extraction and fractionation of } \\
\text { dried ginger essential oil }\end{array}$ & $\begin{array}{l}\text { Supercritical } \mathrm{CO}_{2} \text { extraction } \\
\text { coupled with fractionation }\end{array}$ & $\begin{array}{l}\text { Natural bioactive compounds, such } \\
\text { as vitamins, essential fatty acids, } \\
\text { and flavors }\end{array}$ & Shukla et al. (2019) \\
\hline $\begin{array}{l}\text { Polysaccharide extraction from } \\
\text { pomace ginger }\end{array}$ & Hot water and ultrasonic-assisted & Antioxidant & Chen et al. (2019) \\
\hline Ginger powder extraction & Ultrasonication-assisted extraction & Antioxidant & Hsieh et al. (2020) \\
\hline Ginger essential oil extraction & Supercritical carbon dioxide & Antioxidants, antimicrobials & Marzlan et al. (2020) \\
\hline
\end{tabular}


meatballs color and suppleness are not affected. Proteolytic enzymes also influence color in ginger meatballs (Thompson et al., 1973), livestock, myoglobin, and hemoglobin concentrations, as well as nonenzymatic browning reactions between meat proteins and sugar reduction (Tiven et al., 2007). Whereas, meatballs thickness is influenced by the filler used, type, or meat part (Kusnadi et al., 2012). Ginger phenolic compounds like gingerol and shogaol can prevent peanut oil rancidity (O'Brien, 2004; Indiarto and Rezaharsamto, 2020b). These compounds contain benzene rings and hydroxyl groups to act as primary antioxidants (Lobo et al., 2010; Subroto et al., 2018; Indiarto and Qonit, 2020). Various studies on the functionality of the ginger for food are presented in Table 2 .

\section{Ginger functionality for health}

Ginger also has several other health benefits such as reducing blood glucose in Type 2 diabetes mellitus patients as an anti-pain cream, analgesic, reduces uric acid, and reduces muscle pain. Ginger contains 6gingerol compounds that can lower blood glucose (Sign et al., 2009), increase insulin sensitivity by increasing preadipocyte differentiation of 3T3-L1 adipocytes as glucose uptake in cell membranes (Sekiya et al., 2004). Besides gingerol, shogaol, zingerone, diarylheptanoids, and their derivatives, ginger paradol can inhibit the enzyme cyclooxygenase work. It can reduce biosynthesis or prostaglandin formation, reducing pain intensity (Khan et al., 2008). The concentration of $10 \%$ and $20 \%$ ginger extract cream has been shown to reduce elderly pain (Setyawan and Tasminatun, 2013). Fresh ginger extract from water has optimum efficacy as an analgesic for 25 mins, while extracts from ethanol extraction have analgesic effects for up to $30 \mathrm{mins}$ (Febriani et al., 2018).

Ginger can also be used to lower blood uric acid levels by consuming ginger boiled water extract containing oleoresin and essential oil. Oleoresin and ginger essential oil content that can reduce blood uric acid levels by inhibiting arachidonic acid metabolism and platelet aggregation and can relieve pain by inhibiting cyclooxygenase pathway to inhibit prostaglandin biosynthesis (essential pain mediators) (Pakpahan, 2015). Also, phenolic compounds in ginger 3 $-7 \%$, such as alkaloids and flavonoids, may inhibit xanthine oxidase enzyme activity, thus preventing uric acid formation (Hernani dan Winarti, 2013; Indiarto et al., 2020).

Ginger's efficacy as an anti-inflammatory has been proven, but its effect on pain is unknown. Ginger bioactive compounds like shogaol, gingerol, paradol, and zingerone are anti-inflammatory. These compounds can also inhibit prostaglandin and leukotrienes biosynthesis by inhibiting muscle pain-reducing cyclooxygenase and lipoxygenase (Haghighi et al., 2005). Zingerone can also work as an antioxidant to stabilize or neutralize free radicals (ROS) that cause muscle damage and pain (Peake et al., 2005). Ginger handles pain in NSAIDs the same way, but this red ginger does not show any side effects due to long-term consumption. It was recognized as safe, classified by FDA in Generally Recognized as Safe (GRAS) (Rayati et al., 2017). Table 3 shows various studies on ginger efficacy.

\section{Potential of ginger to increase body immunity and antiviral properties}

In addition to these health benefits, ginger is currently being targeted by the community as it is believed that it can increase the body's immune system to prevent the COVID-19 outbreak. COVID-19 is an infectious disease caused by SARS-CoV-2, a type of coronavirus that spreads through droplets from the respiratory tract such as coughing or sneezing. The lungs are the organs most affected by this virus, as the virus enters its host cells through the angiotensin 2 converting enzyme (ACE2), most commonly found in alveolar lung type II cells. One way to prevent this virus is to increase the immune system of the body to fight the infection when it enters the body (Letko et al., 2020). If the

Table 2. Ginger functionality in foodstuffs

\begin{tabular}{|c|c|c|}
\hline Material form & Food functionality & References \\
\hline $\begin{array}{l}\text { The nanoemulsion-based edible coating } \\
\text { containing ginger }\end{array}$ & Increase the shelf-life of chicken breast fillets & Noori et al. (2018) \\
\hline $\begin{array}{l}\text { Sodium caseinate based on the edible film, } \\
\text { which contains essential ginger oil }\end{array}$ & Prevent lipid oxidation in foods & Atarés et al. (2010) \\
\hline Ginger powder & Prevents soybean oil lipid oxidation & Tinello and Lante (2020) \\
\hline Powdered ginger added to the bread dough & Improving the bread's rheological characteristics & Balestra et al. (2011) \\
\hline Antioxidant-rich ginger candy & Improve candy phytochemical properties & Kumar et al. (2018) \\
\hline $\begin{array}{l}\text { Whey protein isolate with ginger- } \\
\text { polyphenol extract }\end{array}$ & $\begin{array}{l}\text { Inhibiting microbial growth, physicochemical damage, } \\
\text { and taste in Steak. It can also slow muscle softening, } \\
\text { prevent lipid oxidation and extend steak shelf life up to } \\
15 \text { days }\end{array}$ & Chaijan et al. (2020) \\
\hline
\end{tabular}


Table 3. Ginger products and health properties

\begin{tabular}{|c|c|c|c|}
\hline Material form & Compound & Efficacy & References \\
\hline Ginger extract & 6-shogaol & Weakens diabetes neuropathy & Fajrin et al. (2020) \\
\hline Ginger extract & Phenolic compounds & $\begin{array}{l}\text { Prevention of necrotizing } \\
\text { enterocolitis }\end{array}$ & Cakir et al. (2018) \\
\hline Ginger essential oil & Monoterpenes; sesquiterpenes & $\begin{array}{l}\text { Antimicrobial Mycobacterium } \\
\text { spp. }\end{array}$ & Baldin et al. (2019) \\
\hline Ginger extract & Shogaol & $\begin{array}{l}\text { Inhibits oxidative stress and } \\
\text { anticlastogenic }\end{array}$ & Kota et al. (2012) \\
\hline Ginger volatile oil & $\begin{array}{l}\beta \text {-phellandrene; camphene; linalool; geranial; } \\
\text { zingiberene; } \beta \text {-sesquiphellandrene; neral; } \alpha \text { - } \\
\text { bisabolene; } \alpha \text {-curcumene; } \alpha \text {-farnesene and } \alpha \text { - } \\
\text { muurolene }\end{array}$ & $\begin{array}{l}\text { Modulate the function of } \\
\text { lymphocytes and the cellular } \\
\text { immune response }\end{array}$ & Zhou et al. (2006) \\
\hline Fresh ginger extract & Phenolic compounds & $\begin{array}{l}\text { Antivirus human respiratory } \\
\text { syncytial virus (HRSV) }\end{array}$ & Chang et al. (2013) \\
\hline Ginger extract & $\begin{array}{l}\text { 6-gingerol, 6-shogaol, terpenoids citral and } \beta \text { - } \\
\text { phellandrene }\end{array}$ & Anti-inflammatory & $\begin{array}{l}\text { Podlogar and Verspohl } \\
(2012)\end{array}$ \\
\hline $\begin{array}{l}\text { Ginger rhizome } \\
\text { ethanol extract }\end{array}$ & Total polyphenols & $\begin{array}{l}\text { Anticancer (against malignant } \\
\text { melanoma) }\end{array}$ & Danciu et al. (2015) \\
\hline Ginger extract & $\begin{array}{l}\text { 6-paradol; 6-shogaol; methyl 6-gingerol; 1- } \\
\text { dehydro-6-gingerol; 5-, 6-, 8-, and 10- gingerol }\end{array}$ & Anti-inflammatory & Ezzat et al. (2018) \\
\hline Ginger essential oil & Total polyphenols & $\begin{array}{l}\text { Inactivation of Caprine } \\
\text { alphaherpesvirus } 1\end{array}$ & Camero et al. (2019) \\
\hline
\end{tabular}

immune system is weakened, the protective capacity of the body also decreases so that pathogens, including viruses, can grow and multiply in the body, causing severe symptoms and fatal complications (Baratawidjaja and Rengganis, 2009). Therefore, an increase in the body's immune system is significant to protect the body from invading pathogens like viruses and bacteria, identify and destroy cancer cells that appear in the body, and clean old cells and damaged tissue (Sherwood, 2013).

In ginger, bioactive compounds play a role in increasing the body's immune system contained in the oleoresin content and essential oils. The essential ginger oil contains the active compounds zingiberene, $\beta$ sesquiphellandrene, $\beta$-bisabolene, farnesene, and geranyl acetate, widely used for aromatherapy (Jesudoss et al., 2017). Aromatherapy benefits from enhancing the body's immune system work by stimulating nerves, the brain nervous system that plays a role in regulating memory and emotions (Ali et al., 2015). When the body is more relaxed, it can stimulate the physiological response of the nerve, endocrine, or immune system (Institute of Medicine, 1994). Stress is a psychological factor affecting the body's immune system (Segerstrom and Miller, 2004).

Ginger can also increase the body's immune system, as it contains non-nutritional compounds with antioxidant properties. Ginger antioxidants play a role in counteracting free radicals entering the body, so free radicals do not damage the cells of the body's immune system. And cells to optimize the immune system, and antioxidants also play a role in increasing immunostimulatory activity (Andarina and Djauhari, 2017). Ginger is more immunostimulatory than turmeric (Sivagurunathan et al., 2011). The mechanism of the immunostimulant is to correct the imbalance of the immune system by increasing specific or non-specific immunity (Baratawidjaja and Rengganis, 2009). Specific immunostimulants are compounds that can give immune response antigenic specificities, such as vaccines or other antigens. Non-specific immunostimulant, by contrast, is a compound that has no antigenic specificity but may increase the immune response to different antigens or stimulate components of the immune system without antigenic properties such as adjuvants (Saxena et al., 2012).

The use of ginger extract in a beverage provides functional properties to increase endurance. It is indicated by the body's immune response to foreign microbes entering the body and stimulating the proliferation of lymphocytes, which plays a vital role in the body's immune system (Radiati et al., 2003). Ginger extract can provide a therapeutic effect shown by increasing DNA repair, increasing antioxidants, reducing lipid peroxidase, and decreasing DNA damage from radiation to maintain the immune system of the body (Geng et al., 2012).

\section{Conclusion}

Phenolic compounds in ginger had positive effects on food and health. Ginger application in both fields is closely related. Ginger is a natural functional food that provides pharmacological contributions like antioxidants, antihyperglycemic, antimicrobial, 
anticarcinogenic, anti-inflammatory, antitumor, antilipidemic, antimutagenic, and others. It means that whenever you consume ginger, these health effects will either be applied to food or as medicine. Ginger is also thought to be capable of combating common influenza viruses and influenza-like symptoms. Fresh ginger in the airway epithelium proved effective against plaque formation induced by a human respiratory syncytial virus (HRSV). Fresh ginger's role prevents virus adherence and internalization. Due to its properties, ginger is also developed to improve its functionality in the form of nanoparticles as a drug delivery with various advantages to increase prevention.

\section{Conflict of interest}

The authors declare no conflict of interest.

\section{Acknowledgments}

The authors are grateful to the Ministry of Research and Technology/ National Research and Innovation Agency of the Republic of Indonesia; and Universitas Pajadjaran for their facilities and funding support.

\section{References}

Ali, B., Al-Wabel, N.A., Shams, S., Ahamad, A., Khan, S.A. and Anwar, F. (2015). Essential oils used in aromatherapy: A systemic review. Asian Pacific Journal of Tropical Biomedicine, 5(8), 601-611. https://doi.org/10.1016/j.apjtb.2015.05.007

Ali, B.H., Blunden, G., Tanira, M.O. and Nemmar, A. (2008). Some phytochemical, pharmacological and toxicological properties of ginger (Zingiber officinale Roscoe): A review of recent research. Food and Chemical Toxicology, 46(2), 409-420. https://doi.org/10.1016/j.fct.2007.09.085

An, K., Zhao, D., Wang, Z., Wu, J., Xu, Y. and Xiao, G. (2016). Comparison of different drying methods on Chinese ginger (Zingiber officinale Roscoe): Changes in volatiles, chemical profile, antioxidant properties, and microstructure. Food Chemistry, 197 (Part B), 1292-1300. https://doi.org/10.1016/ j.foodchem.2015.11.033

Andarina, R. and Djauhari, T. (2017). Antioksidan dalam Dermatologi. Jurnal Kedokteran dan Kesehatan, 4 (1), 39-48. [In Bahasa Indonesia].

Anita, N., Sartini and Alam, G. (2020). Ginger candy (Zingiber officinale) reduces the frequency of vomiting of first-trimester pregnant women with emesis gravidarum. Enfermería Clínica, 30 (Supplement 4), 536-538. https://doi.org/10.1016/ j.enfcli.2020.03.014
Arablou, T. and Aryaeian, N. (2018). The effect of ginger (Zingiber Officinale) as an ancient medicinal plant on improving blood lipids. Journal of Herbal Medicine, 12, 11-15. https://doi.org/10.1016/ j.hermed.2017.09.005

Atarés, L., Bonilla, J. and Chiralt, A. (2010). Characterization of sodium caseinate-based edible films incorporated with cinnamon or ginger essential oils. Journal of Food Engineering, 100(4), 678-687. https://doi.org/10.1016/j.jfoodeng.2010.05.018

Baldin, V.P., Bertin de Lima Scodro, R., Mariano Fernandez, C.M., Ieque, A.L., Caleffi-Ferracioli, K.R., Dias Siqueira, V.L., de Almeida, A.L., Gonçalves, J.E., Cortez, D.A.G. and Cardoso, R.F. (2019). Ginger essential oil and fractions against Mycobacterium spp. Journal of Ethnopharmacology, 244, $112095 . \quad$ https://doi.org/10.1016/ j.jep.2019.112095

Balestra, F., Cocci, E., Pinnavaia, G. and Romani, S. (2011). Evaluation of antioxidant, rheological and sensorial properties of wheat flour dough and bread containing ginger powder. LWT - Food Science and Technology, 44(3), 700-705. https://doi.org/10.1016/ j.lwt.2010.10.017

Baliga, M.S., Shivashankara, A.R., Haniadka, R., Palatty, P.L., Arora, R. and Fayad, R. (2013). Chapter 11 - Ginger (Zingiber officinale Roscoe): An Ancient Remedy and Modern Drug in Gastrointestinal Disorders. In Watson, R.R. and Preedy, V.R. (Eds.) Bioactive Food as Dietary Interventions for Liver and Gastrointestinal Disease, p. 187-199. San Diego: Academic Press. https:// doi.org/10.1016/B978-0-12-397154-8.00189-5

Baratawidjaja, K.G. and Rengganis, I. (2009). Imunologi Dasar. $8^{\text {th }}$ ed. Jakarta: Fakultas Kedokteran Universitas Indonesia. [In Bahasa Indonesia].

Cakir, U., Tayman, C., Serkant, U., Yakut, H.I., Cakir, E., Ates, U., Koyuncu, I. and Karaogul, E. (2018). Ginger (Zingiber officinale Roscoe) for the treatment and prevention of necrotizing enterocolitis", Journal of Ethnopharmacology, 225, 297-308. https:// doi.org/10.1016/j.jep.2018.07.009

Camero, M., Lanave, G., Catella, C., Capozza, P., Gentile, A., Fracchiolla, G., Britti, D., Martella, V., Buonavoglia, C. and Tempesta, M. (2019). Virucidal activity of ginger essential oil against caprine alphaherpesvirus-1. Veterinary Microbiology, 230, 150-155. https://doi.org/10.1016/ j.vetmic.2019.02.001

Chaijan, S., Panpipat, W., Panya, A., Cheong, L.-Z. and Chaijan, M. (2020). Preservation of chilled Asian sea bass (Lates calcarifer) steak by whey protein isolate coating containing polyphenol extract from ginger, 
lemongrass, or green tea. Food Control, 118, 107400 .

j.foodcont.2020.107400

Chang, J.S., Wang, K.C., Yeh, C.F., Shieh, D.E. and Chiang, L.C. (2013). Fresh ginger (Zingiber officinale) has anti-viral activity against human respiratory syncytial virus in human respiratory tract cell lines. Journal of Ethnopharmacology, 145(1), 146-151. https://doi.org/10.1016/j.jep.2012.10.043

Chen, G.T., Yuan, B., Wang, H.X., Qi, G.H. and Cheng, S.J. (2019). Characterization and antioxidant activity of polysaccharides obtained from ginger pomace using two different extraction processes. International Journal of Biological Macromolecules, 139, 801-809. https://doi.org/10.1016/ j.ijbiomac.2019.08.048

Danciu, C., Vlaia, L., Fetea, F., Hancianu, M., Coricovac, D.E., Ciurlea, S.A., Şoica, C.M., Marincu, I., Vlaia, V., Dehelean, C.A. and Trandafirescu, C. (2015). Evaluation of phenolic profile, antioxidant and anticancer potential of two main representants of Zingiberaceae family against B164A5 murine melanoma cells. Biological Research, 48, 1. https://doi.org/10.1186/0717-628748-1

Ezzat, S.M., Ezzat, M.I., Okba, M.M., Menze, E.T. and Abdel-Naim, A.B. (2018). The hidden mechanism beyond ginger (Zingiber officinale Rosc.) potent in vivo and in vitro anti-inflammatory activity. Journal of Ethnopharmacology, 214, 113-123. https:// doi.org/10.1016/j.jep.2017.12.019

Fajrin, F.A., Nugroho, A.E., Nurrochmad, A. and Susilowati, R. (2020). Ginger extract and its compound, 6-shogaol, attenuates painful diabetic neuropathy in mice via reducing TRPV1 and NMDAR2B expressions in the spinal cord. Journal of Ethnopharmacology, 249, 112396. https:// doi.org/10.1016/j.jep.2019.112396

Febriani, Y., Riasari, H., Winingsih, W., Aulifa, L. and Permatasari, A. (2018). The Potential Use of Red Ginger (Zingiber officinale Roscoe) Dregs as Analgesic. Indonesian Journal of Pharmaceutical Science and Technology, 1, 57-64.

Geng, Y., Du, X., Cao, X., Chen, Y., Zhang, H. and Liu, H. (2012). The therapeutic effects of Zingiber officinale extract on mice irradiated by $60 \mathrm{Co} \gamma$-ray. Journal of Medicinal Plants Research, 6(13), 25902600. https://doi.org/10.5897/JMPR11.767

Haghighi, M., Khalvat, A., Toliat, T. and Jallaei, S. (2005). Comparing the effects of ginger (Zingiber officinale) extract and ibuprofen on patients with osteoarthritis. Archives of Iranian Medicine, 8(4), 267-271.
Hernani dan Winarti, C. (2013). Kandungan Bahan Aktif Jahe dan Pemanfaatannya dalam Bidang Kesehatan. [In Bahasa Indonesia].

Hsieh, Y.H., Li, Y., Pan, Z., Chen, Z., Lu, J., Yuan, J., Zhu, Z. and Zhang, J. (2020). Ultrasonicationassisted synthesis of alcohol-based deep eutectic solvents for extraction of active compounds from ginger. Ultrasonics Sonochemistry, 63, 104915. https://doi.org/10.1016/j.ultsonch.2019.104915

Indiarto, R. and Qonit, M.A.H. (2020). A review of irradiation technologies on food and agricultural products. International Journal of Scientific and Technology Research, 9(1), 4411-4414.

Indiarto, R. and Rezaharsamto, B. (2020a). A review on ohmic heating and its use in food. International Journal of Scientific and Technology Research, 9(2), 485-490.

Indiarto, R. and Rezaharsamto, B. (2020b). The physical, chemical, and microbiological properties of peanuts during storage: A review. International Journal of Scientific and Technology Research, 9(3), 19091913.

Indiarto, R., Nurhadi, B., Tensiska, T., Subroto, E. and Istiqamah, Y.J. (2020). Effect of liquid smoke on microbiological and physico-chemical properties of beef meatballs during storage. Food Research, 4(2), 522-531. https://doi.org/10.26656/fr.2017.4(2).341

Indiarto, R., Pranoto, Y., Santoso, U. and Supriyanto. (2019). In vitro antioxidant activity and profile of polyphenol compounds extracts and their fractions on cacao beans. Pakistan Journal of Biological Sciences, 22(1), 34-44. https://doi.org/10.3923/ pjbs.2019.34.44

Institute of Medicine. (1994). Food Components to Enhance Performance: An Evaluation of Potential Performance-Enhancing Food Components for Operational Rations. Washington, DC: The National Academies Press. https://doi.org/10.17226/4563

Jesudoss, V.A.S., Victor Antony Santiago, S., Venkatachalam, K. and Subramanian, P. (2017). Chapter 21 - Zingerone (Ginger Extract): Antioxidant Potential for Efficacy in Gastrointestinal and Liver Disease. In Gracia-Sancho, J. and Salvadó, J. (Eds.) Gastrointestinal Tissue, p. 289-297. USA: Academic Press. https://doi.org/10.1016/B978-0-12805377-5.00021-7

Khan, A.H., Carson, R.J. and Nelson, S.M. (2008). Prostaglandins in labor - A translational approach. Frontiers in Bioscience, 13(15), 5794-5809. https:// doi.org/10.2741/3117

Kim, J.S. and Kim, M.J. (2010). In vitro antioxidant activity of Lespedeza cuneata methanolic extracts. 
Journal of Medicinal Plants Research, 4(8), 674 679.

Kota, N., Panpatil, V.V., Kaleb, R., Varanasi, B. and Polasa, K. (2012). Dose-dependent effect in the inhibition of oxidative stress and anticlastogenic potential of ginger in STZ induced diabetic rats. Food Chemistry, 135(4), 2954-2959. https:// doi.org/10.1016/j.foodchem.2012.06.116

Kumar, V., Kushwaha, R., Goyal, A., Tanwar, B. and Kaur, J. (2018). Process optimization for the preparation of antioxidant rich ginger candy using beetroot pomace extract. Food Chemistry, 245, 168177. https://doi.org/10.1016/j.foodchem.2017.10.089

Kusnadi, D.C., Bintoro, V.P. and Al-Baarrii, A.N. (2012). Daya Ikat Air, Tingkat Kekenyalan dan Kadar Protein Pada Bakso Kombinasi Daging Sapi dan Daging Kelinci. Jurnal Aplikasi Teknology Pangan, 1(2), 28-31. [In Bahasa Indonesia].

Letko, M., Marzi, A. and Munster, V. (2020). Functional assessment of cell entry and receptor usage for SARS-CoV-2 and other lineage B betacoronaviruses. Nature Microbiology, 5, 562-569. https:// doi.org/10.1038/s41564-020-0688-y

Liao, D.-W., Cheng, C., Liu, J.-P., Zhao, L.-Y., Huang, D.-C. and Chen, G.-T. (2020). Characterization and antitumor activities of polysaccharides obtained from ginger (Zingiber officinale) by different extraction methods. International Journal of Biological Macromolecules, 152, 894-903. https:// doi.org/10.1016/j.ijbiomac.2020.02.325

Lobo, V., Patil, A., Phatak, A. and Chandra, N. (2010). Free radicals, antioxidants and functional foods: Impact on human health. Pharmacognosy Reviews, 4 (8), 118-126. https://doi.org/10.4103/09737847.70902

Mahboubi, M. (2019). Zingiber officinale Rosc. essential oil, a review on its composition and bioactivity. Clinical Phytoscience, 5(1), 1-12. https:// doi.org/10.1186/s40816-018-0097-4

Mahomoodally, M.F., Aumeeruddy, M.Z., Rengasamy, K.R.R., Roshan, S., Hammad, S., Pandohee, J., Hu, X. and Zengin, G. (2019). Ginger and its active compounds in cancer therapy: From folk uses to nano-therapeutic applications. Seminars in Cancer Biology. [In-Press Corrected Proof]. https:// doi.org/10.1016/j.semcancer.2019.08.009

Mao, Q.Q., Xu, X.Y., Cao, S.Y., Gan, R.Y., Corke, H., Beta, T. and Li, H.B. (2019). Bioactive compounds and bioactivities of ginger (Zingiber officinale roscoe). Foods, 8(6), 1-21. https://doi.org/10.3390/ foods 8060185

Marzlan, A.A., Muhialdin, B.J., Zainal Abedin, N.H.,
Mohammed, N.K., Abadl, M.M.T., Mohd Roby, B.H. and Meor Hussin, A.S. (2020). Optimized supercritical $\mathrm{CO} 2$ extraction conditions on yield and quality of torch ginger (Etlingera elatior (Jack) R.M. Smith) inflorescence essential oil. Industrial Crops and Products, 154, 112581. https://doi.org/10.1016/ j.indcrop.2020.112581

Noori, S., Zeynali, F. and Almasi, H. (2018). Antimicrobial and antioxidant efficiency of nanoemulsion-based edible coating containing ginger (Zingiber officinale) essential oil and its effect on safety and quality attributes of chicken breast fillets. Food Control, 84, 312-320. https:// doi.org/10.1016/j.foodcont.2017.08.015

O'Brien, R.D. (2004). Fats and Oils: Formulating and Processing for Applications. Boca Raton: CRC Press.

Pakpahan, T.L. (2015). Manfaat Jahe (Zingiber officinale Roscoe) terhadap Kadar Asam Urat. Jurnal Kesehatan dan Agromedicine, 2(4), 530-535. [In Bahasa Indonesia].

Panjaitan, E.N., Saragih, A. and Purba, D. (2012). Gel Formulation of Red Ginger (Zingiber officinale Roscoe) Extract. Journal of Pharmaceutics and Pharmacology, 1(1), 9-20.

Peake, J., Nosaka, K. and Suzuki, K. (2005). Characterization of inflammatory responses to eccentric exercise in humans. Exercise Immunology Review, 11, 64-85.

Podlogar, J.A. and Verspohl, E.J. (2012). Antiinflammatory Effects of Ginger and Some of its Components in Human Bronchial Epithelial (BEAS2B) Cells. Phytotherapy Research, 26(3), 333-336. https://doi.org/10.1002/ptr.3558

Radiati, L.E., Nabet, P., Franck, P., Nabet, B., Caplaumont, J. and Fardiaz, D. (2003). Pengaruh Ekstrak Diklorometan Jahe (Zingiber officinale Roscoe) Pada Reseptor Sel Hibridoma LV dan CACO-2. Jurnal Teknologi dan Industri Pangan, 14 (1), 59-67. [In Bahasa Indonesia].

Rahimmalek, M. and Goli, S.A.H. (2013). Evaluation of six drying treatments with respect to essential oil yield, composition and color characteristics of Thymys daenensis subsp. daenensis. Celak leaves. Industrial Crops and Products, 42(1), 613-619. https://doi.org/10.1016/j.indcrop.2012.06.012

Ravindran, P.N. and Babu, K.N. (2016). Ginger: The Genus Zingiber, Ginger: The Genus Zingiber. Boca Raton: CRC Press. https:// doi.org/10.1201/9781420023367

Rayati, F., Hajmanouchehri, F. and Najafi, E. (2017). Comparison of anti-inflammatory and analgesic 
effects of Ginger powder and Ibuprofen in postsurgical pain model: A randomized, doubleblind, case-control clinical trial. Dental Research Journal, 14(1), 1-7. https://doi.org/10.4103/17353327.201135

Reis, N.D.S., Santana, N.B.D., Tavares, I.M.D.C., Lessa, O.A., Santos, L.R.D., Pereira, N.M., Soares, G.A., Oliveira, R.A., Oliveira, J.R. and Franco, M. (2020). Enzyme extraction by lab-scale hydrodistillation of ginger essential oil (Zingiber officinale Roscoe): Chromatographic and micromorphological analyses. Industrial Crops and Products, 146, 112210. https:// doi.org/10.1016/j.indcrop.2020.112210

Reis, N.S., Brito, A.R., Pacheco, C.S.V, Costa, L.C.B., Gross, E., Santos, T.P., Costa, A.R., Silva, E.G.P., Oliveira, R.A., Aguiar-Oliveira, E., Oliveira, J.R. and Franco, M. (2019). Improvement in menthol extraction of fresh leaves of Mentha arvensis by the application of multi-enzymatic extract of Aspergillus niger. Chemical Engineering Communications, 206 (3), 387-397. https:// doi.org/10.1080/00986445.2018.1494580

Sahoo, M., Jena, L., Rath, S.N. and Kumar, S. (2016). Identification of Suitable Natural Inhibitor against Influenza A (H1N1) Neuraminidase Protein by Molecular Docking. Genomics and Informatics, 14 (3), 96. https://doi.org/10.5808/GI.2016.14.3.96

Saxena, R., Sharma, A., Bharti, M. and Rathore, M. (2012). Immunomodulator A New Horizon: An overview. Journal of Pharmacy Research, 5(4), 2306 -2310 .

Segerstrom, S.C. and Miller, G.E. (2004). Psychological stress and the human immune system: a metaanalytic study of 30 years of inquiry. Psychological Bulletin, 130(4), 601-630. https:// doi.org/10.1037/0033-2909.130.4.601

Sekiya, K., Ohtani, A. and Kusano, S. (2004). Enhancement of insulin sensitivity in adipocytes by ginger. BioFactors, 22(1-4), 153-156. https:// doi.org/10.1002/biof.5520220130

Semwal, R.B., Semwal, D.K., Combrinck, S. and Viljoen, A.M. (2015). Gingerols and shogaols: Important nutraceutical principles from ginger.Phytochemistry, 117, 554-568. https:// doi.org/10.1016/j.phytochem.2015.07.012

Setyawan, R.A. and Tasminatun, S. (2013). Effectivity of Extract Cream Zingiber officinale Linn. var. Rubrum as lowering of Joint Pain Intensity in Elderly. Mutiara Medika, 13(2), 105-110.

Sharifi-Rad, M., Varoni, E.M., Salehi, B., Sharifi-Rad, J., Matthews, K.R., Ayatollahi, S.A., Kobarfard, F., Ibrahim, S.A., Mnayer, D., Zakaria, Z.A., Sharifi-
Rad, M., Yousaf, Z., Iriti, M., Basile, A. and Rigano, D. (2017). Plants of the genus zingiber as a source of bioactive phytochemicals: From tradition to pharmacy. Molecules, 22(12), 1-20. https:// doi.org/10.3390/molecules22122145

Sherwood, L. (2013). Human Anatomy and Physiology from Cell to System. Canada: Cengage Learning.

Shukla, A., Naik, S.N., Goud, V. V. and Das, C. (2019). Supercritical CO 2 extraction and online fractionation of dry ginger for production of highquality volatile oil and gingerols enriched oleoresin. Industrial Crops and Products, 130, 352-362. https://doi.org/10.1016/j.indcrop.2019.01.005

Shukla, Y. and Singh, M. (2007). Cancer preventive properties of ginger: A brief review. Food and Chemical Toxicology, 45(5), 683-690. https:// doi.org/10.1016/j.fct.2006.11.002

Sign, A., Muraya, R. and Srivastava, K.C. (2009). Anty Hiperglikemic, lipid lowering and antioxidant properties of 6 ginferol in $\mathrm{db} / \mathrm{db}$ mice. Internasional Journal of Medicine and Medical Sciences, 1(12), 536-544.

Sivagurunathan, A., Meera, A.K. and Innocent, B.X. (2011). Investigation Of Immunostimulant Potential Of Zingiber Officinale and Curcuma Longa In Cirrhinus Mrigala Exposed To Pseudomonas Aeruginosa-Haematogical Assessment. International Journal of Research in Ayurveda and Pharmacy 2 (3), 899-904.

Srinivasan, K. (2017). Ginger rhizomes (Zingiber officinale): A spice with multiple health beneficial potentials. PharmaNutrition, 5(1), 18-28. https:// doi.org/10.1016/j.phanu.2017.01.001

Subroto, E., Indiarto, R., Marta, H. and Shalihah, S. (2019). Effect of heat-moisture treatment on functional and pasting properties of potato (Solanum tuberosum 1. var. granola) starch. Food Research, 3 (5), 469-476. https://doi.org/10.26656/fr.2017.3 (5). 110

Subroto, E., Tensiska, Indiarto, R., Marta, H. and Wulan, A.S. (2018). Physicochemical and sensorial properties of recombined butter produced from milk fat and fish oil blend. Bioscience Research, 15(4), 3733-3740.

Sueishi, Y., Masamoto, H. and Kotake, Y. (2019). Heat treatments of ginger root modify but not diminish its antioxidant activity as measured with multiple free radical scavenging (MULTIS) method. Journal of Clinical Biochemistry and Nutrition, 64(2), 143-147. https://doi.org/10.3164/jcbn.18-41

Thompson, E.H., Wolf, I.D. and Allen, C.E. (1973). Ginger rhizome: A new source of proteolytic 
enzyme. Journal of Food Science, 38(4), 652-655.

Tinello, F. and Lante, A. (2020). Accelerated storage conditions effect on ginger- and turmeric-enriched soybean oils with comparing a synthetic antioxidant BHT. LWT - Food Science andTechnology, 131, 109797.

Tiven, N.C., Suryanto, E. and Rusman. (2007). Komposisi Kimia, Sifat Fisik dan Organoleptik Bakso Daging Kambing dengan Bahan Pengenyal yang Berbeda. AgriTECH, 27(1), 1-6. [In Bahasa Indonesia].

Tritanti, A. and Pranita, I. (2019). The making of red ginger (zingiber officinale rovb. var. rubra) natural essential oil. Journal of Physics: Conference Series, 1273, 012053.

Vasala, P.A. (2012). Ginger. In Peter, K.V. (Ed.) Handbook of herbs and spices. Vol. 1, p. 195-206. USA: Woodhead Publishing.

Zhang, M., Xu, C., Liu, D., Han, M.K., Wang, L. and Merlina, D. (2018). Oral delivery of nanoparticles loaded with ginger active compound, 6-Shogaol, attenuates ulcerative colitis and promotes wound healing in a murine model of ulcerative colitis. Journal of Crohn's and Colitis, 12(2), 217-229.

Zhou, H., Deng, Y. and Xie, Q. (2006). The modulatory effects of the volatile oil of ginger on the cellular immune response in vitro and in vivo in mice. Journal of Ethnopharmacology, 105(1), 301-305. 